\title{
BIOSIMILAR MEDICAL PRODUCTS - LICENSING, PHARMACOVIGILANCE AND INTERCHANGEABILITY
}

\author{
Aleksandra Grozdanova, Katerina Ancevska Netkovska, Zoran Sterjev, Zorica Naumovska, \\ Rubin Zarevski, Aleksandar Dimovski, Ljubica Suturkova
}

Pharmaceutical Chemistry Institute, Faculty of Pharmacy, Ss. Cyril and Methodius University, Skopje, R. Macedonia

Corresponding Author: Aleksandra Grozdanova, Faculty of Pharmacy, Ss. Cyril and Methodius University, Skopje, Majka Tereza 47, 1000 Skopje, R. Macedonia; Tel: +38975338786; E-mail: agrozdanova@ff.ukim.edu.mk

\begin{abstract}
The use of biological medicine has significantly increased in recent decades and has made substantial contributions to improving the effectiveness of therapies in many diseases. The expiration of patents of biological innovative medicines enables copies of those drugs called similar biological products (biosimilars) to be approved by regulatory authorities and to enter in clinical use. Biosimilars are comparable but not identical and are not a generic version of the innovator biological product. Although biosimilars undergo rigorous characterization as well as clinical studies to prove their safety and effectiveness, specific regulatory requirements for registration apply in the case of biosimilars. They are highly complex molecules and small changes in the production process can have major implications in its safety and effectiveness profile. The availability of biosimilars enhances competition, with the potential to improve patient access to biological medicines and to contribute to the financial sustainability of healthcare systems. In order to be certain that a biosimilar reaches its potential in clinical use, an intensive pharmacovigilance monitoring system must be established in order to prove the true similarity between the original biologic and its biosimilar. There is a need for further guidance and resolution of the ongoing discussions on biosimilar labelling, naming, pharmacovigilance and substitution in order to ensure effective and appropriate use of biosimilars in clinical practice.
\end{abstract}

Keywords: Regulatory, biosimilars, biologics, licensing, interchangeability, pharmacovigilance, EMA

\section{Background}

Biological medicinal products (biologicals) are produced by or derived from living organisms, most often using genetically modified eukaryotic or prokaryotic cell lines. These medicines, often referred to as "biological drug" or "biologicals" are therapeutic or supplementary proteins such as hormones, hematopoietic growth factors, monoclonal antibodies, blood products, immunological medicinal products like sera and vaccines, or advanced technology products such as DNA molecules, genes and cell therapy products. In terms of size and comple- xity, these molecules are often more than thousand times bigger than chemical medicines, and more complex since they are composed of a string of amino acids, with subunits, and alpha-helix and beta-sheets typically forming the primary, secondary, tertiary or quarterly structure, with loops, pockets and crevices which are critical for their functionality [1].

The production of biologicals is a complex process which involves steps of gene manipulation, fermentation and purification and requires a very high level of technical expertise, sensitivity and precisely controlled condi- 
tions for achieving manufacturing consistency in order to guarantee the safety and efficacy of the final product. Still, because of the posttranslational modification such as glycosylation, oxidation and deamination, the final product can be present in different subtitle batch to batch variants which can have high impact on the functionality of the molecule. Process related impurities such as host cell proteins, DNA or endotoxin have to be controlled and to be in the range of safe limit. Therefore, unlike generics where an exact copy can be made, in the case of production of biological medicinal products - "the process defines the product". Beside the manufacturing process and their molecular size and complexity, biologicals differ from the small molecule medicines in their characterrization, stability, variability and immunogenicity.

Since biologicals have high structural variability that can be very subtle, the currently available analytical techniques are not always sufficient enough to fully characterize them. Though every batch in part has product quality differences, the variations from batch to batch need to be monitored to ensure conformance within an allowed range. Still the product even in its purest form is associated with a number of post translational modifications of the product variants. Thorough characterization of these post translational modifications and other structural variations is scientifically challenging [2]. The product quality differences between batches need to be exactly defined in a regulatory application and correlation to clinical trial results needs to be drawn, to avoid any safety issues. Therefore, "one size fits all" approach of the regulatory review of a small molecule does not fit a biological drug and the variability of biologicals is tightly controlled by manufacturers and regulatory authorities and must remain within defined and accepted limits [3].

Due to the nature of the active substance, biological medicines can be recognized by the human body as "foreign" and can have the potential to induce unwanted immune reactions. In a study from 2007, it was shown that recombinant human insulin was less immunogenic than porcine insulin, but still in $44 \%$ of the diabetes patients there was an increased titer of antibodies towards recombinant human insulin [4]. Immunogenicity is a key safety concern, and is assessed during the development and production of any biological medicinal product, supported in clinical trials by extensive testing and characterization.

\section{What are biosimilars?}

Most of the innovator biological medicine is facing expiration of patents and other data protection and has already lost or will lose its exclusivity in the coming years. This enables copies of those drugs called "similar biological medicinal product" (biosimilars) to be approved by regulatory authorities and thus to enter into clinical use. In general, biosimilars are defined as biological compounds that are highly similar to their already authorized reference biological products, with no clinically meaningful differences in safety, purity and potency. "Biosimilarity" is the regulatory term used first in the European Union (EU) and the European Medical Agency (EMA) to denote the comparability between a biosimilar and its reference medicinal product. Biosimilars are legally approved subsequent versions of innovator biopharmaceutical products following patent and exclusivity expiry. The term "biosimilar" is not a consensus by regulatory agencies and each adopts their own term and definition (Table 1). Despite the existence of slight differences in the guidelines, reference product characteristics and data required for approval among different regions, the basic principles for regulatory requirements are very similar bearing in essence the same meaning world over. However, the definition and nomenclature of biosimilars differs among the various regulatory agencies across the world. For example, they are known as similar biological medicinal products or biosimilars by the EMA [5] and Korean Food and Drug Administration (KFDA), as follow-on protein products or follow-on biologics by the United States of America (USA) Food and Drug Administration (FDA) [6], as similar biotherapeutic product in the World Health Organization (WHO) [7] and as subsequent entry biologics by Health Canada [8]. 
Table 1

Names and definitions of biosimilars according to different regulatory agencies

\begin{tabular}{|l|l|l|}
\hline Agency & Naming & Definition \\
\hline EMA/EU & Biosimilar & $\begin{array}{l}\text { A biological medicinal product that contains a version of the active } \\
\text { substance of an already authorized original biological medicinal product } \\
\text { (reference medicinal product) in the EEA. Similarity to the reference } \\
\text { medicinal product in terms of quality characteristics, biological activity, } \\
\text { safety and efficacy based on a comprehensive comparability exercise } \\
\text { needs to be established. }\end{array}$ \\
\hline FDA/USA & $\begin{array}{l}\text { Follow-on Biologic } \\
\text { or Follow-on protein } \\
\text { products }\end{array}$ & $\begin{array}{l}\text { A biological product that is highly similar to an U.S.-licensed reference } \\
\text { biological product notwithstanding minor differences in clinically } \\
\text { inactive components, and for which there are no clinically meaningful } \\
\text { differences between the biological product and the reference product in } \\
\text { terms of the safety, purity, and potency of the product. }\end{array}$ \\
\hline WHO & $\begin{array}{l}\text { A biotherapeutic product which is similar in terms of quality, safety, } \\
\text { and efficacy to an already licensed reference biotherapeutic product. } \\
\text { biotherapeutic } \\
\text { product }\end{array}$ & $\begin{array}{l}\text { Biosimilar } \\
\text { KFDA/Korea }\end{array}$ \\
\hline $\begin{array}{l}\text { Health } \\
\text { Canada/ } \\
\text { Canada }\end{array}$ & $\begin{array}{l}\text { Subsequent entry } \\
\text { biologic }\end{array}$ & $\begin{array}{l}\text { A biological product which demonstrated its equivalence to an already } \\
\text { approved reference product with regard to quality, safety, and efficacy. } \\
\text { subsequent to an approved innovator biologic product. }\end{array}$ \\
\hline
\end{tabular}

Due to these scaled down market authorization requirements for biosimilars, it is expected that pharmaceutical companies can produce biosimilars at a lower cost while ensuring their quality, safety and efficacy. Licensing requirements for biosimilars do not include all elements of a complete dossier for the approval of a new medicine, but are still more demanding than the requirements for the approval of generics [9]. Because of the complexity of their active substance and the specificity of the production process, biosimilars cannot be produce with exactly the same characteristics as the reference medicine. Therefore biosimilars undergo rigorous characterization, preclinical and clinical comparability studies to prove their similarity, safety and effectiveness profile [3]. The extensive product approval process in the EU establishes the therapeutic equivalence and interchangeability of a biosimilar for the innovator biological product and requests additional post-marketing surveillance of biosimilars. Still, substitution of innovator product with biosimilars is not addressed and has been left to be decided by the national authority level by each country. The aim of this review is to provide an overview of the regulatory aspects for licensing of biosimilars in the EU, outlining some key issues for biosimilars like naming, interchangeability, substitution, pharmacovigilance and their impact in the future clinical practice.

\section{Licensing of biosimilars in the $\mathbf{E U}$}

The EU is the leader in establishing a regulatory framework for marketing authorization of biosimilars. The EMA and the European Commission were the first to implement a well-documented legal pathway for the approval of biosimilar products that are different from the generic pathway. Specific data requirements in terms of the analytical, preclinical, and clinical data have been specified in the guidelines for biosimilars, which are more detailed than those for generics. If we compare the requirements for biosimilar licensing pathway with regards to the generic (small molecule) and innovator biological products the differences are that for the generic ones the data are for quality, purity and stability, and for the new biologic medicine, beside those three, there are the data for potency, immunogenicity, stability and full preclinical and clinical studies, while for biosimilars there is an extra comparability module and post-marketing monitoring, while the 
preclinical and clinical data are abbreviated. After the initial wave of patent expiration of innovator biological drugs, the EMA in 2005 released the first biosimilar guidelines [10], and the approval for the first biosimilar (somatropin) came in 2006. The requirements for marketing authorization of biosimilars were defined in specific guidance for biosimilars, based on the principle of comparative quality and clinical pharmacokinetic and pharmacodynamic studies, nonclinical and clinical studies, and limited toxicology studies, as well as comparative clinical efficacy and tolerability studies. EMA first released general guidelines for quality, nonclinical and clinical issues which addressed the quality, consistency, the manufacturing process, safety, and efficacy considerations. This was followed by more detailed productspecific guidelines, by EMA/Committee for Medicinal Products for Human Use (CHMP), for products like erythropoietin, growth hormone, granulocyte colony stimulating factor (GCSF), insulin, interferon beta, low-molecular weight heparins, and monoclonal antibodies. Additional guidance and recommendations followed to ensure the safety and efficacy of biosimilar products [11-13]. The list of some of the main guidelines can be found in Table 2 and Table 3 (available at the EMA web site under the section of scientific guidelines, at http://www.ema.europa.eu/docs/en_GB/docum entlibrary/Scientific_guideline)

Table 2

\section{Overarching EMA guidelines relevant to biosimilar development and approval}

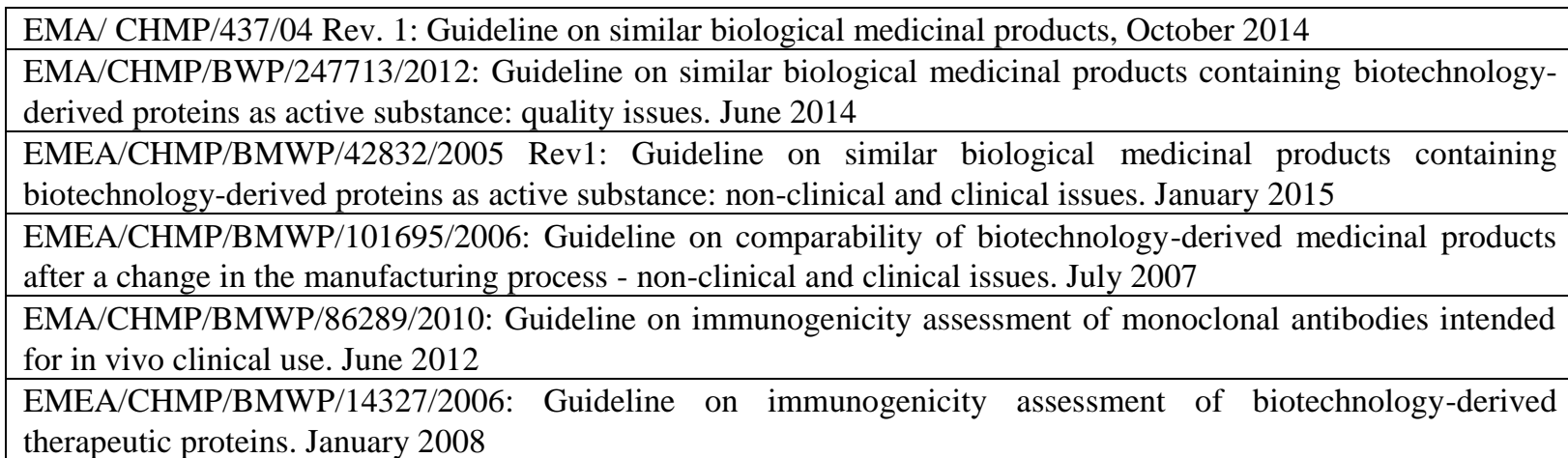

Table 3

\section{Product-specific EMA guidelines relevant to biosimilar development and approval}

CHMP/BMWP/671292/2010 Guideline on similar biological medicinal products containing recombinant folliclestimulating hormone. March 2013

CHMP/BMWP/652000/20100 Guideline on similar biological medicinal products containing interferon beta. March 2013

EMA/CHMP/BMWP/403543/2010 Guideline on similar biological medicinal products containing monoclonal antibodies: non-clinical and clinical issues. June 2012

EMEA/CHMP/BMWP/301636/08 Guideline on similar biological medicinal products containing recombinant erythropoietins. April 2010

EMEA/CHMP/BMWP/118264/2007 Guideline on similar biological medicinal products containing lowmolecular-weight heparins. April 2009

EMEA/CHMP/BMWP/102046/2006 Guideline on non-clinical and clinical development of similar medicinal products containing recombinant interferon alpha. June 2009

The EU guidelines for biosimilars to date stand as one of the most stringent regulatory norms for biosimilar product development. Until several years ago, the production of biosimilars was mainly directed towards the development of simple protein therapeutics like granulocyte colony stimulating factor, erythropoietin, somatropins, and follitropins. However, recently, in 2013 two biosimilar monoclonal antibodies of infliximab have been granted marketing 
authorization, indicating that complex molecules are starting to gain biosimilar status in the EU. The EMA has the longest list of approved biosimilars after the implementation of biosimilar guidelines. At the moment in the EU/EMA there are current market authorization for 19 biosimilars, in 6 classes as follow: one insulin, five epoetins, two follitropin alfa, one somatropin, seven filgrastim and two monoclonal antibodies (Table 4 ).

Table 4

EMA-approved biosimilars (October, 2015)

\begin{tabular}{|l|l|l|l|l|}
\hline & Product Name & Active Substance & Marketing Authorization Holder & $\begin{array}{l}\text { Authorization } \\
\text { date }\end{array}$ \\
\hline 1 & $\begin{array}{l}\text { Abasaglar } \\
\text { Abasria) }\end{array}$ & insulin glargine & Eli Lilly Regional Operations GmbH & $09 / 09 / 2014$ \\
\hline 2 & Epoetin Alfa Hexal & epoetin alfa & Hexal AG & $28 / 08 / 2007$ \\
\hline 3 & Binocrit & epoetin alfa & Sandoz GmbH & $28 / 08 / 2007$ \\
\hline 4 & Abseamed & epoetin alfa & Medice Arzneimittel Pütter GmbH \& Co.KG & $28 / 08 / 2007$ \\
\hline 5 & Silapo & epoetin zeta & Stada Arzneimittel AG & $18 / 12 / 2007$ \\
\hline 6 & Retacrit & epoetin zeta & Hospira UK Limited & $18 / 12 / 2007$ \\
\hline 7 & Ovaleap & follitropin alfa & Teva Pharma B.V. & $27 / 09 / 2013$ \\
\hline 8 & Bemfola & follitropin alfa & Finox Biotech AG & $27 / 03 / 2014$ \\
\hline 9 & Omnitrope & somatropin & Sandoz GmbH & $12 / 04 / 2006$ \\
\hline 10 & Tevagrastim & filgrastim & Teva GmbH & $15 / 09 / 2008$ \\
\hline 11 & Ratiograstim & filgrastim & Ratiopharm GmbH & $15 / 09 / 2008$ \\
\hline 12 & Biograstim & filgrastim & AbZ-Pharma GmbH & $15 / 09 / 2008$ \\
\hline 13 & Zarzio & filgrastim & Sandoz GmbH & $06 / 02 / 2009$ \\
\hline 14 & Filgrastim Hexal & filgrastim & Hexal AG & $06 / 02 / 2009$ \\
\hline 15 & Nivestim & filgrastim & Hospira UK Ltd. & $08 / 06 / 2010$ \\
\hline 16 & Grastofil & filgrastim & Apotex Europe BV & $18 / 10 / 2013$ \\
\hline 17 & Accofil & filgrastim & Accord Healthcare Ltd & $18 / 09 / 2014$ \\
\hline 18 & Remsima & infliximab & Celltrion Healthcare Hungary Kft. & $10 / 09 / 2013$ \\
\hline 19 & Inflectra & infliximab & Hospira UK Limited & $10 / 09 / 2013$ \\
\hline & & & & \\
\hline
\end{tabular}

The EU is the leading biosimilar market, which is evident from the number of approved drugs, market size, launched guidelines, and other regulatory aspects. The EMA requirements to approve biosimilars vary according to the class of molecule, and decisions occur case by case. The EMA requirements for comprehensive comparability studies between the biosimilar and reference products are elaborately defined in the EMA guidelines. The EMA guidelines are some of the most stringent, considering the diversity and complexity of the biological products. The regulatory legislation for biosimilars in the EU have clarified many aspects of their development, and many countries have adopted their own guidelines based on the EMA publications. The EMA has a robust regulatory process and the guidelines are continually revised and updated based on the experience obtained with the approval of biosimilars over time [14]. However, there are some challenges in areas such as bio analytics and comparability assay development, the definitions of biological activity under clinical view, the global harmonization of acceptable data, and product commercialization strategies of biosimilars [15]. Immunogenicity, one of the most serious adverse effects, has been observed during the therapeutic use of innovator biological products, which causes additional safety concerns among biosimilar regulators. Up to now there have been no clear specifications for analytical tests or preclinical and clinical studies to demonstrate biosimilarity in relation to a reference product. The reference product for demonstration of biosimilarity continues to be the one approved by the European Economic Area (EEA). To promote global development of biosimilars and to avoid the repetition of clinical trials, the revised guideline states that alternati- 
vely certain clinical studies and in vivo nonclinical studies could be conducted with nonEEA authorized reference product providing justification and bridging studies. This reference is acceptable for a product authorized by a regulatory authority with similar scientific and regulatory standards as the EMA [16]. The development of biosimilar processes is very flexible due to the numerous possibilities and benefits available, such as disposable technology for production, supply chain logistics, and modern in-process analytical methods for process development and validation [17]. Changes that occurred over the time which were added by the experience gained by application reviews, led to an updated draft guideline released in 2013 and adopted by the Committee for Medicinal Products for Human Use (CHMP) on October, 2014. [16]. Case-by-case analysis is an approach used by the EU to deal with the diversity and complexity of biologics taking into consideration the class of the biologic which is under review [9].

\section{Nomenclature of biosimilars}

Currently, according to the International Nonproprietary Names (INN) mode of nomenclature established by the WHO, biological medicines are classified in a therapeutic group based on the active substance, and this scheme has been recognized by all the regulatory agencies. On the basis on this policy, the INN for a new biosimilar can be the same as that of the original biologic medicine [18]. In such case, when only the INN without a distinguishable identifier is used when prescribing and using a biologic and biosimilar medicine, an adverse event may be difficult to attribute to a specific product. That would lead to questions on what medicine caused the adverse event, leading to an unclear ability to document long-term product safety [19]. Each biosimilar product should be readily distinguishable from the reference product and other biosimilars in order to ensure appropriate use, traceability, and accurate reporting of adverse drug reaction (ADR) [20]. Different countries have addressed this issue on specific way and have adopted their own policies for biosimilar naming. For example in Japan, according to the guidance released by the Pharmaceuticals and Medical Devices Agency, the Japanese regulatory agency non-proprietary names of biosimilars should contain, at the end of the name, the respective follow-on number (e.g., biosimilar 1, 2, or 3), and the proprietary name should contain the BS letters, in addition to the dosage form, dosage, and name of the manufacturer [21]. Another issue is that some national regulatory authorities have licensed biologicals that are intended to be a copy of the innovator so called "intended copies", even though the development there was not conducted in a rigorous, stepwise comparison with the reference product, according to the EU guidance and the WHO recommendations. In those countries, particularly in new emerging markets, the lack of specific regulatory guidance for naming of biologicals and biosimilars, or the existence of different approval pathways currently represents a substantial challenge for all involved parties and stakeholders, including clinicians, pharmacists and patients, who may be confronted, as a consequence, with the approval and use of 'intended copies' or non-comparable versions of biologic products. The fact that these copies of biologics often share the same INNs as the reference products underscores why having an INN qualifier unique to the manufacturer would be advisable from a traceability and patient-safety perspective.

\section{Pharmacovigilance of biosimilars}

Naming of biosimilar products has important implications for physicians' prescripttion, potential patient bias, and interchangeability, as well as pharmacovigilance. As indicated by the WHO, national regulatory agencies need to ensure accurate ADR reporting for marketed biological medicines, by requiring inclusion of proprietary (brand) name, manufacturer's name, lot number, and country of origin, in addition to the INN [22]. Often the pharmacovigilance system in a given country is not implemented based on high regulatory and efficiency standards, and it may not be possible to detect safety signals related to specific intended copy products or for biosimilars. To address this issue, the WHO is currently developing guidance on a risk-based approach. At the last meeting in 2014, the WHO acknowledged the need to distinguish biosimilar products. In August 2014, the WHO released a draft proposal for adding a 4-letter code, or "biological qualifier" to all biologics, in addition to the INN, and to establish a more 
robust system for the identification of biosimilars and other biologics [23]. While the adoption of the biological-qualifier system would be a voluntary decision by individual regulatory authorities, it would represent an important tool for global harmonization.

\section{Interchangeability and substitution}

Other regulatory challenge is related to the interchangeability and/or substitution. These terms are often used as synonyms in the US, but not in the EU. According to the European Generic Medicines Association (EGMA), interchangeability refers to the prescription of a biosimilar in place of the reference product by prescribers, while substitution means that pharmacists are allowed to dispense a biosimilar [24]. Substitution of generic drugs for reference drugs is used because the two medicines are considered identical if they have demonstrated bioequivalence. However, since biosimilar drugs are not exact copies and the generic approach cannot be applied in the case of biosimilars, the question whether they can be substitutes of original biologics remains unclear. Interchangeability and substitution of biosimilars are not within the scope of the EU regulatory approval and, hence, there is no an agreement on the definition of what interchangeability actually means and no inclusion of such information in the European public assessment reports (EPAR) [14]. The EU regulators are considering biosimilars as "therapeutic alternatives" to the reference product, which would allow a biosimilar to be switched for the reference product either at the initiation or during the therapy. However, the European Consensus document released by the European Commission notes that interchangeability implies an initiative or agreement by the prescriber, and that patients should speak to their physician and pharmacist about switching decisions and changing therapy from one biologic product to another [14]. EMA does not have the authority to designate a biosimilar as automatically substitutable and currently, regulatory decisions concerning substitution are left to individual countries [25]. The EMA does not guarantee interchangeability and established that these aspects are beyond its competence. Therefore, authorities of each Member State should decide after scientific evaluation perfor- med by the CHMP and other data submitted to the regulatory agency on support of the request [26].

Automatic drug substitution is the decision to switch a product for another product at the pharmacy level without the consent of the prescribing physician. Automatic substitution is generally confined to true generic drugs, which are chemically derived products that can be identical to their reference product in terms of chemical composition. Specific implementtation of automatic drug substitution is independently regulated by each European country. In practice in the case of biologics, substitution is construed as the legal authority for a hospital or a pharmacy filling a prescription to switch from dispensing the innovator product to a biosimilar or the reverse. A lack of clear guidelines on this issue and the consequence of substitution of one biological medicine for another can severely impact patient safety and make post-marketing pharmacovigilance more difficult. The issue of substitution is also closely tied to naming because if doctors prescribe biologics by a unique identifier, rather than by the currently used INN, the substitution of a biosimilar product when dispensed by a pharmacist would likely occur much less often. In practice, substitution by a pharmacist of a biosimilar for a reference biopharmaceutical medicine is not allowed in any European country [27] and is not recommended by the World Health Organization or by medical societies. The EMA also advises that the physician should be in charge of the decision to switch between the reference and biosimilar, or vice versa [28]. The major concern about interchangeability is that repeated switches between the biosimilars and the reference biological may increase immunogenicity, leading to adverse reactions. Some inherent differences arising due to a post approval process or a formulation change could lead to differential immunogenicity that may not necessarily be accessed through characterization or clinical trials during the time of application/approval, but may become evident during the post approval surveillance and pharmacovigilance. Even during pharmacovigilance the studies are typically designed on patient population and never follow a single patient, making it very difficult to track the status of interchan- 
geability issues. Therefore, it would be difficult for regulatory bodies to certify that the drug is truly interchangeable without adequate data. There has been considerable debate over this issue in all regulatory agencies. According to the EMA, the approved biosimilar status signifies that the biosimilar can be used interchangeably with reference drugs. However, automatic substitution is not possible according to the EU pharmaceutical law governing similar biological medicinal products. The EMA in a public consultation for the revision of the 2005 Guideline has included a new element where in a statement it mentions that a biosimilar application when assessed for marketing authorization does not certify the interchangeability status. Since these provisions come under the national laws of the EU Member States, the EMA does not have the power to make such determination. According to the EMA, automatic substitution does not apply for any approved biosimilar. The EU Generics Association also claims that more than 12 countries have rules against automatic substitution. However, France has now permitted the switching of biosimilars and generics with the originals as part of a new Social Security Budget Legislation (article 47), which came into effect on January 1, 2014 [29]. Overall, due to the intense efforts from the originator manufacturers concerning health risks and differences of biosimilars in relation to the reference product, giving uncertainty for prescribers and patients, the application of interchangeability and/or substitution is limited. Still the use of biosimilars in the clinic practice may have a positive impact in the near future, leading the way towards adequate decisions [30].

\section{Conclusion}

The EMA has established a tied regulatory framework for the licensing of biosimilars, but these requirements are inadequate for fully establishing the efficacy, safety and clinical use of biosimilars. The questions of naming and nomenclature of biosimilars, interchangeability and substitution, pharmacovigilance and the degree of comparability between a biosimilar and the reference need to be considered. The differences in the national health care systems, regulatory and reimbursement authorities in the EU member states and in other counties, can lead towards different policy decisions on use of biosimilars. There is a need for more comparative studies in order to collect the data necessary to follow up on and evaluate uncertainties surrounding the longer-term safety, effectiveness, and cost-effectiveness of a biosimilar, as compared to the current standard treatment. Biosimilars are here to stay, and beside approval from quality and safety regulatory aspects, even more important is the confidence of health authorities, doctors, and patients in the efficacy and safety of biosimilars.

\section{REFERENCES}

1. Dolinar RO, Reilly MS. The future of biological therapy: a pathway forward for biosimilars. GaBI Journal. 2013; 2(1): 36-40.

2. Berkowitz SA, Engen JR, Mazzeo JR, Jones GB. Analytical tools for characterizing biopharmaceuticals and the implications for biosimilars. Nat Rev Drug Discov. 2012; 11 (7): 527-540.

3. Weise M, Bielsky MC, De Smet K, Ehmann F, Ekman N, Giezen TJ, et al. Biosimilars: what clinicians should know. Blood 2012; 120 (26): 5111-5117.

4. Fineberg SE, Kawabata TT, Finco-Kent D, Fountaine RJ, Finch GL, Krasner AS. Immunological responses to exogenous insulin. Endocr Rev. 2007; 28: 625-652.

5. EMA/CHMP/437/04 Rev 1. Guideline on Similar Biological Medicinal Products. Available at:

http://www.ema.europa.eu/docs/en_GB/document_librar y/Scientific_guideline/2014/10/WC500176768.pdf.

6. FDA. Information for Consumers (Biosimilars). Available at:

http://www.fda.gov/Drugs/DevelopmentApprovalProces s/HowDrugsareDevelopedandApproved/Approval/Appli cations/TherapeuticBiologicApplications/Biosimilars/uc m241718.htm.

7. WHO Expert Committee on Biological Standardization. Guidelines on evaluation of similar biotherapeutic products (SBPs). Available at:

http://www.who.int/biologicals/areas/biological_therape utics, Biotherapeutics for web_22april 2010.pdf.

8. Health Canada. Fact Sheet: Subsequent Entry Biologics in Canada. Available at:

http://www.hc-sc.gc.ca/dhp-mps/brgtherap/activit/fs-

fi/fs-fi_seb-pbu_07-2006-eng.php.

9. Wang J, Chow SC. On the regulatory approval pathway of biosimilar products. Pharmaceuticals (Basel). 2012; 5(4): 353-368.

10. EMA. Guideline on similar biological medicinal products. 2005. Available at:

http://www.ema.europa.eu/docs/en_GB/document_librar y/scientific_guideline/2009/09/WC500003517.pdf.

11. EMA. Guideline on Similar Biological Medicinal Products Containing Monoclonal Antibodies-Nonclinical and Clinical Issues. 2012. Available at: 
http://www.ema.europa.eu/docs/en_GB/document_librar y/scientific_guideline/2012/06/WC500128686.pdf

12. EMA. Guideline on Immunogenicity Assessment of Monoclonal Antibodies Intended for In Vivo Clinical Use. 2012 Available at:

http://www.ema.europa.eu/docs/en_GB/document_librar y/scientific_guideline/2012/06/WC500128688.pdf

13. EMA. Guideline on Good Pharmacovigilance Practices. 2013 Available at:

http://www.ema.europa.eu/docs/en_GB/document_librar y/Scientific_guideline/2013/04/WC500142282.pdf

14. Consensus Information Paper 2013. What you need to know about Biosimilar Medicinal Products. European Commission. Available at:

http://ec.europa.eu/enterprise/sectors/healthcare/files/doc s/biosimilars_report_en.pdf.

15. McCamish M, Woollett G. Worldwide experience with biosimilar development. MAbs. 2011; 3: 209217.

16. EMA. Guideline on Similar Biological Medicinal Products. 2001. Available at:

http://www.ema.europa.eu/docs/en_GB/document_librar y/Scientific_guideline/2014/10/WC50017.pdf

17. Scott C. A decade of process development. BioProcess Int. 2012; 10: 72-78.

18. World Health Organization Executive Summary. Proceedings of the $55^{\text {th }}$ Consultation on International Nonproprietary Names for Pharmaceutical Substances, Geneva, 16-18 October 2012.

www.who.int/medicines/services/inn/55th_Executive_Su mmary.pdf.

19. Silverman E. Biosimilars: what's in a name? BMJ 2014; 348: g272

20. Casadevall N, Edwards IR, Felix T, Graze PR, Litten JB, Strober BE, Warnock DG. Pharmacovigilance and biosimilars: considerations, needs, and challenges. Expert Opin Biol Ther 2013; 13: 1039-47.

21. The Pharmaceuticals and Medical Devices Agency, Japan. March 2009 Guideline for the Quality, Safety, and Effectiveness of Biosimilar Products. Tokyo: Pharmaceuticals and Medical Devices Agency.

22. World Health Organization. Apr 2009. Guidelines on Evaluation of Similar Biotherapeutic Products. Geneva: World Health Organization Expert Committee on Biological Standardization.

23. World Health Organization. Jan 2014. Regulatory Expectations and Risk Assessment for Biotherapeutic Products: Scientific Principles to Consider.

24. European Generic Medicines Association. Biosimilars Handbook, 2nd ed. 2011, Brussels: European Generic Medicines Association.

25. Dörner T, Strand V, Castañeda-Hernández G, Ferraccioli G, Isaacs JD, Kvien TK, Martin-Mola E, Mittendorf T, Smolen JS, Burmester GR (2013) The role of biosimilars in the treatment of rheumatic diseases. Ann Rheum Dis. 72: 322-328.

26. EMA. Questions and Answers on Biosimilar Medicines, 2012. Available from:
http://www.ema.europa.eu/docs/en_GB/document_librar y/Medicine_QA/2009/12/WC500020062.pdf.

27. Rovira, J, Espin J, Garcia L, Olry de Labry A. The Impact of Biosimilars' Entry in the EU Market. Andalusian School of Public Health. 2011. Available at: http://citeseerx.ist.psu.edu/viewdoc/download?doi510.1. 1.357.2218\&rep5rep1\&type5. pdf.

28. Jelkmann W. Biosimilar epoetins and other "followon" biologics: update on the European experiences. Am J Hematol. 2010; 85: 771-780.

29. France to allow biosimilars substitution. 2014. Available at:

http://www.gabionline.net/Policies-Legislation/Francetoallow-biosimilars-substitution/(highlight)/france $\% 20$ substitution.

30. Weise M, Kurki P, Wolff-Holz E, Bielsky MC, Schneider CK. Biosimilars: the science of extrapolation. Blood. 2014; 124: 3191-3196.

Резиме

\section{БИОСЛИЧНИ МЕДИЦИНСКИ ПРОИЗВОДИ - РЕГИСТРАЦИЈА, ФАРМАКОВИГИЛАНЦА И ЗАМЕНЛИВОСТ}

\section{Александра Грозданова, Катерина Анчевска-Нетковска, Зоран Стерјев, Зорица Наумовска, Александра Капедановска-Несторовска, Рубин Заревски, Александар Димовски, Љубица Шутуркова}

Институт за фармацевтска хемија, Фармацевтски факултет, Универитет „Св. Кирил и Методиј“, Скопје, Р. Македонија

Употребата на биолошките лекови е зголемена во последните декади и тоа резултираше со значителен придонес кон подобрување на ефективноста од терапијата кај многу заболувања. Истекувањето на патентната заштита на биолошките иноваторни лекови овозможи да се јават на пазарот таканаречените слични биолошки производи (биослични) кои беа одобрени од регулаторните агенции за клиничка употреба. Биосличните лекови се слични, но не се идентични и не се генеричка верзија на иноваторните биолошки производи. Иако биосличните лекови минуваат ригорозна карактеризација како и клиничките студии со цел да се докаже нивната безбедност и ефективност, сепак, постојат специфични регулаторни барања за регистрација на биосличните лекови. Ова се многу комплексни молекули и мали промени во процесот на производство може да имаат големо влијание 
на нивната безбедност и ефикасност. Појавата на биосличните лекови ја зголеми компетитивноста, со можност да се подобри достапноста на биолошките лекови до пациентите и да продонесе кон одржување на финансиска стабилност на здравствените системи. За да се искористи потенцијалот на биосличните лекови во клиничката пракса, мора да се обезбеди интензивен фармаковигиланца мониторинг-систем со цел да се потврди вистинската сличност меѓу ориги- налниот и биосличниот лек. Оттука е и потребата од насоки и водичи за јасно дефинирање на постоечката дебата за обележување, именување, фармаковигиланца и супституција со цел да се обезбеди ефикасна и соодветна употреба на биосличните лекови во клиничката пракса.

Клучни зборови: регулатива, биосимилари, биолошки лекови, лиценцирање, заменливост, фармаковигиланца, ЕMА 